\title{
CONCEPTUAL BASIS FOR THE FORMATION OF THE AGRICULTURAL LAND MARKET PURPOSES
}

\author{
${ }^{I}$ Buiak L. M. Dr. in Economic, Associate Professor, \\ ${ }^{2}$ Pryshliak K. M. Phd Student \\ ${ }^{1}$ Ukraine, Ternopil, Ternopil National Economic University, Head of economic cybernetics and \\ informatics department, \\ ${ }^{2}$ Ukraine, Ternopil, Ternopil National Economic University
}

DOI: https://doi.org/10.31435/rsglobal_ijite/01062018/5678

\author{
ARTICLE INFO \\ Received 30 April 2018 \\ Accepted 26 May 2018 \\ Published 01 June 2018

\section{KEYWORDS} \\ model, \\ land market, \\ moratorium, \\ rent
}

(C) 2018 The Authors.

\author{
ABSTRACT \\ In this paper, the conceptual model that describes a wide range \\ of phenomena and processes that will begin in Ukraine's economy after the \\ abolition of the moratorium on land sales. Based on this model, a number of \\ basic conclusions.
}

Today it is obvious that the problem of introducing sustainable land use in Ukraine requires further strengthening of the effective state regulation of market land relations. An important task for activating economic activity and business development in the country is the creation of conditions for the maximum full and unhindered provision of economic entities by land parcels of the appropriate purpose in order to realize investment projects, increase production capacities, develop transport infrastructure, etc.

Particularly relevant is the study of ways to solve this problem in agriculture, because it is just like any other industry of the country's economy is closely linked to the use of natural resources, primarily land. Land is the main resource of human development in the countryside, but it will perform this function only with the condition of consolidation of agricultural land use and formation of effective agribusiness market-type.

The concept of what the land market in Ukraine should be is in the process of formation. There are quite opposite views and points of view: from the formation of the exclusively land lease market to the removal of any restrictions on the transfer of ownership / trade in agricultural land

The research of the formation of the land market was undertaken by such scientists as I. R. Mykhasiuk, Ye. Y. Maiovets, Yu. D. Bilyk, L. Ya. Novakovskyi, V. E. Dankevich, V. M Zaiats, A. S Danilenko. Economists such as V. Andriichuk, E. Yanushevich, P. Onyshenko, O. Gutorova, Yu. Lupenko, O. Shpichak and others engaged in problems of introduction and use of land resources.

The questions on the theoretical justification for the introduction of the agricultural land market are devoted to the work of such foreign scientists as D. Ahner, S. Gliessmann, L. Vranken, R. Just, D. Hueth, A. Schmitz, M. Przychodzeń, E. Laskowska. R. Simpson. The issue of state regulation of land relations in the EU member states is studied in the works of J. Swinnen, P. Ciaian, A. Kancs, K. Van Herck, L. Vranken.

Highly appreciating the scientific achievements of the named scientists, it can be noted that under current conditions, land relations require further in-depth study as part of the substantiation of the directions for their further improvement in the near future and the study of the necessary conditions for this.

Creation and effective functioning of the land market in Ukraine is an objectively necessary measure of state importance that will provide a solution to a complex of existing problems, the main of which is the legalization, control and regulation of transactions concerning sale and purchase of land, 
which is practically already happening but uncontrollably, as well as the possibility of using land as a real mortgage for a loan through a land mortgage.

In a market economy, land, like any other means of production, is a commodity, has a price, is bought and sold, its use is paid, all operations with land are carried out taking into account the value of land [1, p.133]. Owning a land parcel without the right to its alienation, pledge, donation, etc. does not meet the criteria for determining the right of private property [2, p. 219].

In the scientific literature there is no single definition of the concept of the land market. The views of scientists on the definition of the land market are divided. Some believe the land market is a process of transfer of rights to use land from some subjects to others. Other, that the land market - is, first of all, the definition of the value of land and recognition of its capital on a par with other means of production and working capital.

Often, there is a misunderstanding of the essence of the land market, which is often treated very narrowly, reducing it only to the purchase of land. But this is an erroneous interpretation of the land market. Even in countries with highly organized market relations, the sale and purchase of agricultural land is limited in scope and, according to some researchers, is only 1-3\% of their total area.

So, after analyzing the statements of various economists, including the above-mentioned authors, we will present the land market as a system of socio-economic relations, where land acts as a commodity and capital in the process of realizing the economic interests of market players.

Often, to understand the essence of the land market is possible through the functions that it performs, the main of them are [7]:

1. Stimulative - is that the market encourages producers to the most rational use of land, because the effectiveness, in particular, of commodity agricultural production, depends to a large extent on the efficiency of the use of land resources.

2. Regulatory function is that the land market provides market redistribution of land between the agrarian sector and other sectors of the economy, between legal entities and individuals.

3. Control function. The essence of this function is that the market is constantly monitoring the process of appropriating land, reducing the cost of acquiring land, provides for a constant comparison of cash incomes of the population with prices for land.

4. The pricing function is realized in the process of formation of land prices, based on specific market conditions.

5. The informative function is that the land market provides information to market participants about the available supply and demand for land, the state and prospects for the development of this market, prices and rent for land, prices for land mortgages, etc.

In Ukraine, the land market does not fulfill its functions, such as: determining the real value of land, regulating land allocation processes, stimulating the effective use of land resources, informing market players about prices, the state of demand and supply through a moratorium on land purchase and sale.

The deceleration of the imposition of a market for agricultural land has led to: the formation of a "shadow" land market; lack of a mechanism for the formation of an effective owner and producer of agricultural products; considerable lag behind the size of the rent from the land rent, which leads to the impoverishment of land owners; lack of a mechanism for attracting loans secured by property rights and use of agricultural land; lowering state incomes that could be earmarked for infrastructure development and rural areas; land raiding; social tension in society; the concentration of land resources by agroholdings, which became regional monopolists and use a cheap land resource, exhausting its crop rotation violations in pursuit of profits, etc. [8].

When forming an effective model for the introduction of agricultural land markets, the following threats need to be taken into account: predatory redemption of land by foreigners; buying land by wealthy buyers and creating latifundia with wage workers; the occupation of great lands by banks in the process of transfer of mortgaged land into the ownership of the mortgagee; the purchase of land by financial speculators and their quick resale, which will affect the cost of agrarian products and will lead to inflation. Therefore, the opening of the land market today requires the adoption of many well-considered and well thought-out decisions.

The most important condition for the establishment of a full-fledged land market is the approval of private ownership of land, which grants the right to own, use and dispose of it. There should also be an economic motivation to enter the land market of land plot sellers and their buyers. At the same time, buyers should have adequate solvency and the opportunity to receive a reasonable income for them from entrepreneurial activity in the field of agricultural production. In turn, this requires the creation of a favorable economic environment and infrastructure of the land market. 
Foreign experience in the development of land ownership relations suggests that in developed countries there are two types of agricultural land markets - lease and purchase. However, the last turns less than $3 \%$ of the land. In the countries of Western Europe, the share of own land tenure in the total area of farmland land use reaches $65 \%$, rental use - $33 \%$. The dispersal of these indicators by country is very high: from almost complete absence of lease (Ireland) to lease more than half of the area (France, Belgium). In the United States in 2005, the share of land occupied by farmers only on their own land was $28 \%$, only leased - $12 \%$, combined use of own and leased land - $60 \%$ [1, p.76]. Detailed analysis of foreign experience of land-lease relations was conducted by Kovtunovich NL and Kondratenko N.G. [1]. The authors conclude that land lease has become the main type of land relations in developed countries. The most efficient use of land leased for the medium and long term. In most developed countries (the Netherlands, Denmark, Spain, Belgium, Portugal, France, Norway, Germany, Japan, etc.) the minimum lease ranges from 6 to 15 years [1, p. 21]. Especially notable is the practice of countries such as France, the Netherlands and Poland. In the legislation of these countries, the orientation is chosen for lifetime use, or the right to long-term lease. The French legislation regulates four types of lease terms: at 9, 18, 25 years - and before the end of employment. Especially attractive form of lease in France is emphyteusis. This is a long-term lease of agricultural land for a period of at least 18 years and not more than 90 years. Emphioteisis is characterized by a low rent (half or even a third of the normal level), as well as the ability to transfer to a pledge, to sublease. In Poland, the right to long-term lease can last up to 99 years, but not less than 40 years. Both France and the Netherlands imposed strict requirements for the professional training of applicants for land lease, experience in the agricultural sector and the availability of seed capital.

After analyzing foreign experience, one can conclude that there are two opposite tendencies in the current land market: the predominance of supply over demand (buyer's market); predominance of demand over supply (seller's market). Balanced market conditions practically absent and substantially differentiated by types of land plots of different administrative subordination.

After analyzing the experience of foreign countries in the field of land use, it should be noted that for the development of land lease land in Ukraine, the main focus should be on the formation of a competitive environment among potential tenants of the land; protection of the rights of peasantslandlords; increase of land rent, introduction of environmental monitoring and control aimed at using tenants of ecologically safe agrotechnologies and proper reproduction of soil fertility. It is advisable to introduce a mortgage mechanism for the right to lease land, since this process does not lead to a change in the owner of the land, but for the tenant to have a significant benefit - it will allow to attract significant funds for the development of production. The model of medium- and long-term lease of land may be oriented towards further redeployment of lease, inheritance or redemption contracts. In this case, it is expedient to establish a scale of motives and restrictions on the resale of purchased agricultural land.

The formation of the land market will be facilitated by the development of mortgage lending, which will ensure the use of agricultural land as collateral. The implementation of the proposed measures will facilitate the attraction of investments in agricultural production, increase the efficiency of use and protection of land, and, most importantly, will ensure that citizens will realize their rights regarding the use of land ownership.

In general, we can state: world experience shows that the regulation of the land market is much more effective than driving it "into the shadow." Legislation of many European countries presupposes the existence of a system for regulating agricultural land turnover, having (due to the characteristic historical or national peculiarities) the economic or social situation in each country, its differences. A detailed analysis of the history of land relations in Europe makes it possible to conclude that the agricultural land market has the right to exist, but it requires careful substantiation and substantial restrictions. An attempt to take into account only the most significant limitation: the prohibition of excessive concentration of land, the right to land those who it is, avoiding the creation of land estates, limiting fragmentation of land, reserve land for public purposes, etc. - leads us to the conclusion that perhaps a reasonable basis for the organization The land market for agricultural purposes is a lease.

The main conditions for the formation of the land market in Ukraine are: the formation of an appropriate legislative and regulatory framework that will create the preconditions for the existence of a regulated land market; availability of land for sale; availability of solvent demand for land; creation of such a method of pricing, which would take into account all the factors that determine its value; developed system of state regulation of the land market at the local, regional and national levels; availability of 
appropriate market infrastructure; creation of an appropriate system of state support for producers of commodity agricultural products, ensuring requirements for the effective use of land plots [9].

An important role in the formation of the land market is played by information that characterizes both individual plots of land and land resources in general. State technology of land parceling is formed on the basis of information, restrictions on land use are established, funds are determined for the purchase of the land, registration of rights to land is established, taxes and fees associated with market turnover of land are established and levied, etc.

When choosing the right model of land market in Ukraine some positive results can be achieved. The increase of the revenue from land efficiency, reducing the "gray" market, The of the increase the investment attractiveness of land, the increase of the local and state budgets, creating new jobs in rural areas. However, the desired result can only be supported by the state, and create an appropriate legal framework.

However, as the land market in Ukraine will only start to develop, the application of these methods is not sufficiently effective, and sometimes even gives false results. It is worth noting that the price largely determines the size of demand for land, but there are also non-price factors that can be divided into two main categories - external and internal.

External factors depend on the macroeconomic environment in which the land market functions, including political, administrative and legal circumstances. Unpredictable changes in the credit, financial, tax and agrarian policy of the state restrain development and lead to abuses in the land market. The influence of internal factors on the demand on the land market is due to the connection of land with a specific territory. This group of factors includes the location of land, the infrastructure of the locality, the environment, as well as demographic and economic circumstances.

Based on the foregoing, the most suitable in this situation is a model approach of determining the price of land and a comprehensive studying of all processes and phenomena associated with the land market, which will begin after the completion of the land reform and the abolition of the moratorium on the land sale.

That is why we propose a model of the functioning of the agricultural land market, which consists of five blocks: the legal basis for the formation of the land market, the objects of the land market, market elements, functions and market segments, whose interaction ensures the rational use of land (pic.1)

In the proposed model, not all agricultural land are considered to be the goods in the market, but only agricultural landowners of private ownership (land shares - shares), obtained by the peasants during the dispersal of the lands of former collective agricultural enterprises. The main "players" in this market are landowners (potential sellers / landlords) and private farmers, non-state agricultural enterprises and large vertically integrated companies (agroholdings) as potential buyers / tenants.

The main assumptions about the functioning of the land market were as follows:

- Agricultural land and rights to them are market goods

- In the land market (as in any market), the formation of the price of goods is primarily determined by the balance of demand and supply.

The offer of goods depends on its availability (the number of unpacked land), the number of potential sellers (the total number of peasants who received land shares) and their readiness for the transaction. In turn, the demand for goods depends on the number of potential buyers, their willingness to conduct the transaction and the price of the goods.

Having carried out qualitative analysis following conclusions were made:

1) the tenure of pensioners decreases over time;

2) individual owners of land plots begin to sell their land plots;

3) the ownership of small and large agricultural enterprises will increase over time (however, if the growth of small enterprises is a consequence of the revival of the Ukrainian economy, the increase of large landowners testifies to the beginning of the process of global land acquisition by a small part of the population);

4) the price of the aggregated industrial product tends to increase, which, combined with an increase in the number of enterprises, indicates improvement of the state of Ukraine's economy and the exit from the crisis;

5) a sharp decline in land prices in the first half of 2012, immediately after the abolition of the moratorium on the sale of agricultural land, due to the high volume of land offerings. Subsequently, land prices will tend to rise.

Consequently, the constructed conceptual model of the agricultural land market makes us think about the consequences of introducing a free market for agrarian lands. The steady increase in land holdings of large, non-equilibrium enterprises threatens the disappearance of the peasantry, as a 
distinctive industrial and socio-cultural structure, as well as economic security. In order to avoid this, the state needs to take appropriate measures to restrict the growth of large agroholdings, and at the same time to stimulate the development of small and medium-sized agricultural enterprises. measures:

To provide the efficient functioning of the agricultural land market, we propose the following

- carrying out a complete inventory of land and land with the definition of the most valuable land (in economic terms), to ensure control of the state;

- realization of land zoning for their functional and purposeful purposes;

- conducting a cadastral assessment of land for the purpose of forming an electronic database;

- creation of accessible and long-lasting information database for access to statistical information on operations with land plots;

- creation of a mechanism of movement of land parcels and compensation for them;

- introduction of amendments to the current legislation concerning reduction of taxes on income from operations with land plots;

- formation of the land market infrastructure.

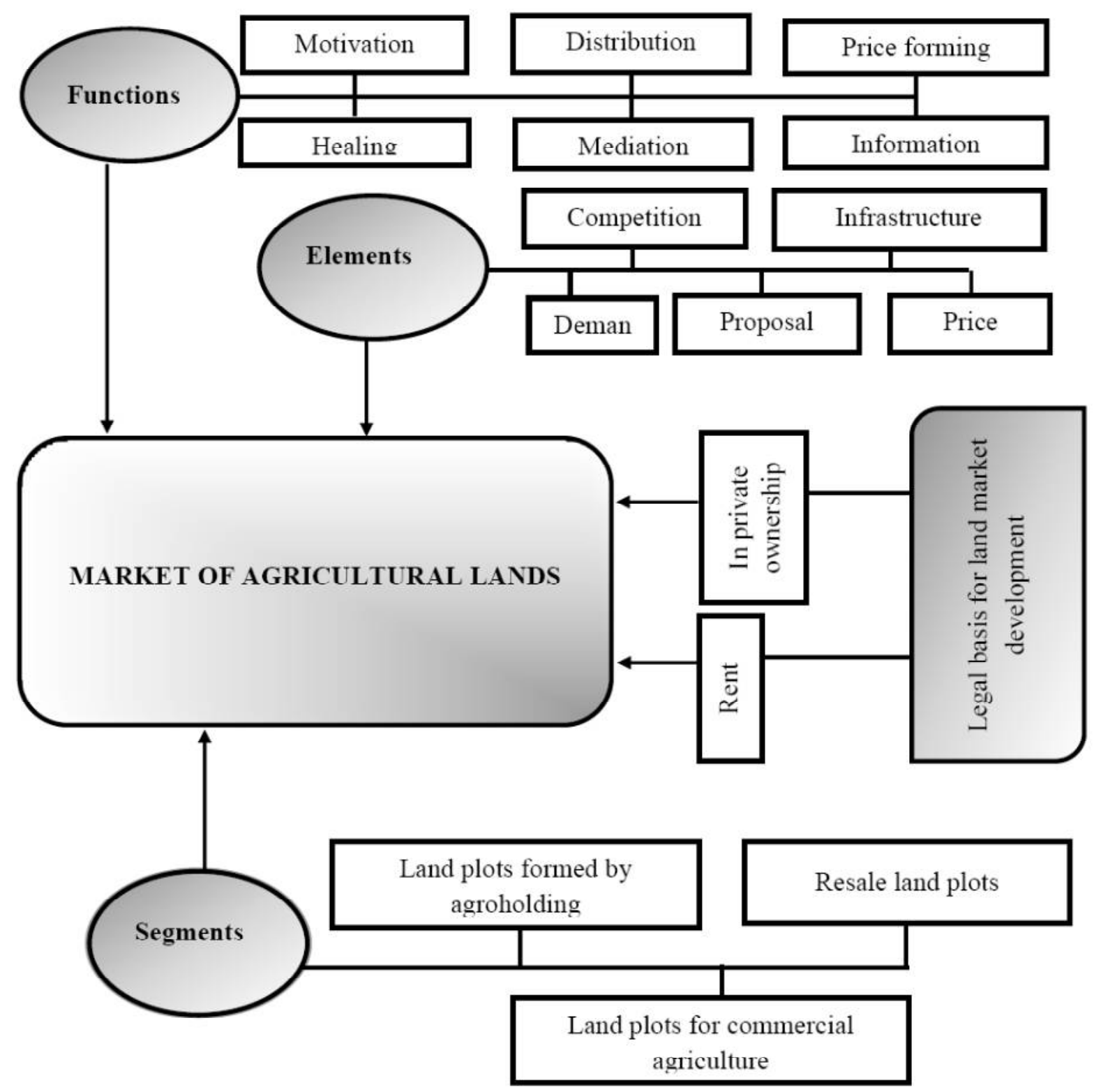

Fig. 1. Model of the agricultural land market functioning 


\section{REFERENCES}

1. Buiak L. M. Modelyuvannya ekonomichnoyi dynamiky z urakhuvannyam rynku zemli sil's'kohospodars'koho pryznachennya 「monohrafiya] / V.S. Hryhorkiv, L. M. Buiak, S. V. Ishchenko. - Chernivtsi: CHNU. Vydavnytstvo «Ruta», 2015. - 360s.

2. Buiak L. M. Dynamichna makromodel' ekonomiky z urakhuvannyam rynku zemli / L. M. Buiak, S. V. Ishchenko // Finansova systema Ukrayiny. Zbirnyk naukovykh prats'. Seriya «Ekonomika» - Ostroh: Vydavnytstvo natsional'noho universytetu «Ostroz'ka akademiya», 2011.Vypusk 16.-592-599.3. Danylenko A. S. Formuvannya rynku zemli v Ukrayini / A. S. Danylenko, YU. D. Bilyk. - K. : Vyd-vo "Urozhay", 2006. - 277 s.

3. Zhuk O. Teoretychni osnovy formuvannya rynku zemel'nykh dilyanok ta yoho infrastruktury / O. Zhuk, O. Shevchenko // Zemleustriy, kadastr i monitorynh zemel'. - 2013. - № 3. S. $61-67$.

4. Lishchenyuk T. M. Formuvannya infrastruktury rynku zemli: avtoref. na dys. na zdobuttya nauk. stupenya kand. ekon. nauk: 08.07.02 «Ekonomika sil's'koho hospodarstva i APK» / Instytut ekonomiky ta prohnozuvannya NAN Ukrayiny. - K., 2006. - $24 \mathrm{~s}$.

5. Sal'nykova T. V. Rynok zemli: chy hotova Ukrayina do n'oho ta yaki naslidky nese znyattya moratoriyu / T. V. Sal'nykova, YE. O. Kolyesnik, I. S. Silina // Molodyy vchenyy. - 2017. № 3. - S. 824-829.

6. Semeryak YU. A. Rynok zemli v Ukrayini: sut', zavdannya, funktsiyi / YU. A. Semeryak, M. H. Moskva// Naukovyy visnyk NLTU Ukrayiny. - 2010. - Vyp. 2014. - S 257-263.

7. Ozhelevs'ka T.S., Rynok zemli sil's'kohospodars'koho pryznachennya v Ukrayini: problemy ty perspektyvy zaprovadzhennya / T. S. Ozhelevs'ka, M. O. Korolik // Molodyy vchenyy 2017. - №10(50). - S. 968-971.

8. Fedorov M. M. Osoblyvosti formuvannya rynku zemel' sil's'kohospodars'koho pryznachennya v Ukrayini / M. M. Fedorov // Ekonomika APK. - 2007. - № 5. - S. 73-78.

9. Yanushevych Ye. Formuvannya rynku zemli na rehional'nomu rivni ta stymulyuvannya yiyi vykorystannya (na prykladi L'vivshchyny) / YE. Yanushevych // Rehional'ni aspekty rozvytku i rozmishchennya produktyvnykh syl Ukrayiny : zb. nauk. prats' Ternopil's'koyi ANH. - Ternopil', 2000. - Vyp. 4. - S. 108-109. 